\title{
A laboratory inter-comparison of the importance of serum serotonin levels in the measurement of a range of radiation- induced bystander effects: Overview of study and results presentation.
}

Fiona Lyng

Technological University Dublin, fiona.lyng@tudublin.ie

C. Mothersill

McMaster University, Ontario, Canada.

F. Antonelli

Instituto Superiore de Sanita

See next page for additional authors

Follow this and additional works at: https://arrow.tudublin.ie/scschphyart

\section{Recommended Citation}

Mothersill, C. et al. (2012) A laboratory inter-comparison of the importance of serum serotonin levels in the measurement of a range of radiation-induced bystander effects: Overview of study and results presentation. Int J Radiat Biol. 2012 Oct;88(10):763-9.

This Article is brought to you for free and open access by the School of Physics \& Clinical \& Optometric Science at ARROW@TU Dublin. It has been accepted for inclusion in Articles by an authorized administrator of ARROW@TU

Dublin. For more information, please contact

arrow.admin@tudublin.ie, aisling.coyne@tudublin.ie, gerard.connolly@tudublin.ie.

Funder: European Commission

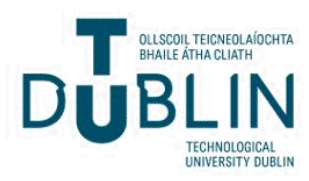




\section{Authors}

Fiona Lyng; C. Mothersill; F. Antonelli; V. Dini; M. Kämäräinen;; and B. Schilling-Tóth

This article is available at ARROW@TU Dublin: https://arrow.tudublin.ie/scschphyart/94 
A laboratory inter-comparison of the importance of serum serotonin levels in the measurement of a range of radiation-induced bystander effects: Overview of study and results presentation

\author{
${ }^{* 1} \mathrm{C}$. Mothersill, ${ }^{2} \mathrm{~F}$. Antonelli ${ }^{3} \mathrm{~J}$. Dahle, ${ }^{2} \mathrm{~V}$. Dini , ${ }^{4} \mathrm{H}$. Hegyesi ${ }^{5} \mathrm{G}$. Iliakis, \\ ${ }^{6} \mathrm{M}$. Kämäräinen, ${ }^{6} \mathrm{~V}$. Launonen, ${ }^{4} \mathrm{~K}$. Lumniczky, ${ }^{7} \mathrm{~F}$. Lyng, ${ }^{4} \mathrm{G}$. Safrany, ${ }^{6} \mathrm{~S}$. Salomaa, \\ ${ }^{4}$ B. Schilling-Tóth, ${ }^{2}$ M.A. Tabocchini, ${ }^{8}$ M.A. Kadhim, **
}

$1{ }^{*}$ Corresponding author: Department of Medical Physics and Applied Radiation Sciences, McMaster University, Hamilton, Ontario, L8S 4K1, Canada. Phone: +1 905525 9140. Email: mothers@mcmaster.ca, 2. Ionising Radiation Biophysics and Biomedical Physics Unit, Technology and Health Department, Istituto Superiore di Sanità , Viale Regina Elena 299, 00161 Rome, Italy, 3. Department of Biophysics, Institute for Cancer Research, The Norwegian Radium Hospital, Montebello, 0311 OSLO, NORWAY, 4. F. Joliot-Curie National Research Institute for Radiobiology and Radiohygiene, Anna u. 5, Budapest 1221, Hungary, 4. Institute of Medical Radiation Biology, University of Duisburg-Essen, Medical School, Hufeland Str. 55, 45122 Essen, Germany, 6. STUK - Radiation and Nuclear Safety Authority, Laippatie 4, P.O. BOX 14, 00881 Helsinki, Finland, 7. Radiation and Environmental Science Centre, Focas Institute, Dublin Institute of Technology, Camden Row, Dublin 8, Ireland, 8. Department of Biological and Medical Sciences - Faculty of Health and Life Sciences, Oxford Brookes University, Headington Campus, Headington Hill, Oxford OX3 OBP, UK

\title{
Short title: NOTE-IP serotonin inter-laboratory study
}

Keywords: Radiation-Induced Bystander effect, serotonin, inter-laboratory comparison, low dose effects, ionizing radiation

for groups where a full paper is included in the special issue only the principal investigator is listed here as an author. Where a group put their data in this combined paper, the individuals contributing to the work are all listed. 


\section{Abstract}

Purpose: Recent research has suggested that serotonin may play an important role in the expression of radiation-induced bystander effects. Serotonin levels in serum were reported to range from $6-22 \mu \mathrm{M}$ and to correlate inversely with the magnitude of cellular colony forming ability in medium transfer bystander assays. That is high serotonin concentration correlated with a low cloning efficiency in cultures receiving medium derived from irradiated cells.

Methods: Because of the potential importance of this observation, the European Union's Non-targeted Effects Integrated Project (NOTE) performed an inter-comparison exercise where serum samples with high and low serotonin levels were distributed to seven laboratories which then performed their own assay to determine the magnitude of the bystander effect.

Results: The results provided some support for a role for serotonin in four of the laboratories. Two saw no difference between the samples and one gave inconclusive results. In this summary paper, full data sets are presented from laboratories whose data was inconclusive or insufficient for a full paper. Other data are published in full in the special issue

Conclusion: The data suggest that there may be multiple bystander effects and that the underlying mechanisms may be modulated by both the culture conditions and the intrinsic properties of the cells used in the assay.

\section{Overall Introduction and summary data from the}

\section{7 laboratories}

While the existence of radiation-induced bystander effects (RIBE) is not in doubt, there are considerable frustrations and uncertainties concerning the reproducibility of experiments both within and between laboratories. See for example (Mothersill and Seymour 1998, Nagar et al, 2006, Groesser et al, 2008, Ryan et al, 2008, Fournier et al, 2009, Cherubini et al, 2011, Zyuzikov et al, 2011, ). A possible explanation for this was published recently (Mothersill et al, 2010). This paper suggested that serum serotonin levels might be critical to the mechanism of signal production and demonstrated a correlation between the level of serotonin in serum batches and the magnitude of the reduction in cloning efficiency of cells receiving medium from irradiated cells. The same authors had earlier demonstrated that serotonin endogenously present in $\mathrm{nM}$ amounts in serum was bound by type $3 \mathrm{~A}$ serotonin receptors in HPV-G cells (human keratinocytes transfected with human papilloma virus) following irradiation (Poon et al 2007). These receptors are calcium channels and open in response to serotonin binding (Ferriere et al, 1997), thus triggering the calcium pulse which has been identified as an early (maybe first) step in the process leading to a bystander effect (Lyng et al, 2002). Inhibitors of 
these receptors prevent the bystander effect (Saroya et al 2009, Fazzari et al, this issue).

Given the potential importance of this finding both for resolving the reproducibility issue and elucidating mechanisms, the European Union NOTE (Nontargeted effects) Integrated Project led by Prof Sisko_Salomaa, decided to run an inter-laboratory exercise to test the importance of serotonin in a wide range of bystander assays in use by group members. These assays include mitochondrial DNA deletion, chromosomal instability assay, micronucleus assay, clonogenic assay, G2 arrest, caspase assay and viability assay. This paper and the special issue report the results of this exercise. Where data were sufficient to produce a full paper for the special issue, only a summary is given in Table 1 . Where results were inconclusive or insufficient for a full paper, they are reported in full in this summary paper. Due to the importance of keeping the data from each laboratory separate, table and figure numbers define the data belonging to each partner laboratory. These relate to the finding of the laboratory under which they are reported.

\section{Methods and Results}

\section{Selection and distribution of serum samples}

The McMaster University laboratory screened 10 serum batches sourced locally and from the United States. Each sample was used in the normal culture medium preparation as follows; A $500 \mathrm{ml}$ bottle of RPMI (Roswell Park Memorial Institute) - 1640 (Gibco-Biocult, , Grand Island, New York, USA) was selected and wrapped in aluminium foil to prevent loss of serotonin though photo-degradation (http://www.chemicalbook.com/ChemicalProductProperty_EN_CB0245131.htm ). The medium was aliquoted in $50 \mathrm{ml}$ lots under low light conditions into 10 foil wrapped $100 \mathrm{ml}$ containers. $5 \mathrm{ml}$ of test serum was added together with $1 \mathrm{ml}$ penicillin streptomycin solution (Gibco-Biocult ) and $1 \mu \mathrm{g} / \mathrm{ml}$ final concentration of hydrocortisone (Sigma-Aldrich, St Louis Missouri, USA, ). A medium transfer RIBE assay was performed and the serum serotonin level was determined as reported previously (Mothersill et al, 2010). After the assay was complete, the cloning efficiency (CE) of the cells from different serum lots was determined. The serum with the highest serotonin level $(22 \mu \mathrm{M})$ corresponded with the lowest $\mathrm{CE}$ in the bystander assay. The serum with the lowest serotonin level $(6 \mu \mathrm{M})$ corresponded with the highest CE in the assay. These sera were chosen for the intercomparison exercise. The chosen batches were then coded and shipped using a dry shipper to Oxford Brookes University in the UK for distribution to the partners. At all times samples were kept foil wrapped to avoid photodegradation according to the chemical description in the weblink (http://www.chemicalbook.com/ ChemicalProductProperty_EN_CB0245131.htm)

The partners involved in this exercise are listed on table 1 together with the assay and result. 
The detailed assay protocols and results obtained for each laboratory not submitting a full paper follow:

\section{Radiation and Nuclear Safety Authority (STUK )}

\section{Protocol}

\section{Cell culture:}

Human TK6 lymphoblastoid cell line was maintained in RPMI 1640 medium (Lonza, Walkersville, MD, USA) containing $200 \mathrm{mM}$ gluthamine, $1 \%$ of penicillin/streptomycin (Gibco Invitrogen, Paisley, UK) and supplemented with $10 \%$ of fetal bovine serum (serum \#6, serum\#9 or GIBCO serum (\#S) lot. 41G5670F, Gibco Invitrogen, Paisley, UK) in humidified incubator at $37^{\circ} \mathrm{C}$ in an atmosphere of $5 \%$ CO2 in air. After arriving serum samples \#6 and \#9 were kept at $-20{ }^{\circ} \mathrm{C}$ for 11 days before using them in assay medium. $100 \mathrm{ml}$ of medium was prepared with different serum samples which were enough for one experiment.

\section{Co-culturing and $X$-ray irradiations}

Bystander effect was analysed by co-culture assay system using permeable cell culture inserts (\#353092, BD Biosciences, NC, USA). Cells were seeded at density of $2.5 \times 10^{5}$ in $2 \mathrm{ml}$ of complete medium into 6-well plates (irradiated) or cell culture inserts (bystander) just prior to irradiations. Cells were irradiated with 0,$1 ; 1$; 2 Gy X-rays with dose rate of $55 \mathrm{mGy} / \mathrm{min}$ for $0,01 \mathrm{~Gy}, 213 \mathrm{mGy} / \mathrm{min}$ for $1 \mathrm{~Gy}$, and $245 \mathrm{mGy} / \mathrm{min}$ for $2 \mathrm{~Gy}$. Sham irradiated cells were transferred along the $2 \mathrm{~Gy}$ irradiated cells.

Immediately after irradiations inserts with bystander cells were combined with irradiated cells and co-cultured for 1 hour. Irradiated cells from 6-well plates or bystander cells from six co-culture inserts were pooled with their equivalent groups into T25 cell culture flasks. From this stage onwards all the samples were analysed coded.

\section{Cell viability}

Cell proliferation kit I (MTT, 3-[4,5-dimethylthiazol-2-yl]-2,5-diphenyl tetrazoliumbromid))(Roche Diagnostics $\mathrm{GmbH}$, Mannheim, Germany) was used to determinate the cell proliferation rates of different groups. Cells were counted with automated cell counter (Countess ${ }^{\circledR}$, Invitrogen, CA, USA). 10x $10^{4}$ cells from each base and insert groups were seeded into 96-well plate (6 parallels) and cultured for20 hours. After that $10 \mu \mathrm{l}$ of MTT reagent was added into wells and culturing was continued for 4 hours. During this incubation period purple formazan crystals were formed from MTT tetrazolium salt by metabolic active cells. Crystals were solubilized with solubilization solution by incubating plates overnight in the cell culture incubator. The solubilised formazan dye was spectrophotometrically measured using an ELISA (enzyme-linked immunosorbent assay) reader with wavelength of $595 \mathrm{~nm}$. 


\section{Caspase-3 assay}

To study the possible involvement of apoptotic events in changes of cell proliferation the activation of caspase- 3 was measured (CaspACE ${ }^{\mathrm{TM}}$ Assay System, Colorimetric, Promega, WI, USA). 24 hours after 1-hour co-culturing period cells were harvested, lysed and total protein concentrations of cell extracts were quantified. $100 \mu \mathrm{g}$ of total protein from each sample was used in the assay and all samples were analysed as triplicates.

\section{Results}

\section{Cell Viability assay}

With doses of 0.1 and 1 Gy TK6 bystander cells grown with the serum \#6 showed decreased cell viability whereas cells grown with the serum \#9 and \#S showed slightly but significantly increased cell viability compared to control level.

\section{Caspase assay}

To analyse whether apoptotic events were contributed to potential changes of cell viability we analysed caspase- 3 activity. In bystander cells the activity was slightly below the control level with all analysed serum samples. Thus the noticed decreased viability of the bystander cells incubated with the serum \#6 was not probably due to activation of apoptosis cascade.

\section{Conclusions}

An opposite effect on bystander cell viability was detected with the high and low serotonin concentration serum patches with doses of 0.1 and $1 \mathrm{~Gy}$. Due to small amount of serum the assays were performed only once which makes the final interpretation of the results difficult.

\section{Radiation and Environmental Science Centre Dublin}

Full paper in this issue.

\section{Istituto Superiore di Sanità}

\section{Protocol}

\section{Cell culture}

AG01522 primary normal human fibroblasts from the same frozen vial were thawed and cultured from the beginning in the different media [alpha-Minimal Essential Medium, with $1 \mathrm{mM}$ glutamine, 2\% Hepes (1M) and antibiotics (all reagents from Gibco Invitrogen, Paisley, UK), supplemented with different sera, 
namely serum A, B, 6 and 9]. They were sub-cultured twice and then used for the experiment.

Day -2

The day before plating, 8 inserts (FALCON, pores of $1.0 \mu \mathrm{m}$, cell growing area of $4.5 \mathrm{~cm}^{2}$ ) were put in 6 wells companion plates in the presence of medium without serum and left at $37^{\circ} \mathrm{C}$ overnight.

\section{Day -1}

$24 \mathrm{~h}$ before irradiation AG01522 cells from each of the 4 independent cultures were seeded:

- in one well in each of two Falcon Companion plates (one Companion plate to be $0.5 \mathrm{~Gy}$ irradiated and the other one to be sham irradiated) at the cell density of $5.0 \times 10^{3} \mathrm{cells} / \mathrm{cm}^{2}\left(4.8 \times 10^{4} \mathrm{cell} / \mathrm{well}\right)$.

- in two inserts (bystander cells) at the cell density of $1.4 \times 10^{4} \mathrm{cell} / \mathrm{cm}^{2}(6.3 \mathrm{x}$ $10^{4}$ cell/insert)

\section{Day 0}

One hour before irradiation, medium was removed from cells seeded in Companion plates and, after 2 washes with phosphate buffered saline (PBS), fresh medium was added $(5 \mathrm{ml} /$ well).

One Companion plate was irradiated with $0.5 \mathrm{~Gy}$ of gamma rays at room temperature, the other one was sham irradiated.

Immediately after, inserts with bystander cells were emptied out of the medium and transferred into the Companion plates (Sham and $0.5 \mathrm{~Gy}$ irradiated). 2 $\mathrm{ml}$ of medium were taken from each Companion well and put into each insert. Companions and inserts were incubated for $30 \mathrm{~min}$ at $37^{\circ} \mathrm{C}$.

At the end of the incubation, inserts were moved into new Companion wells (with no cells seeded) together with their "conditioned" medium. Cytochalasin B at the final concentration of $1.5 \mu \mathrm{g} / \mathrm{ml}$ was added to the medium and samples were incubated at $37^{\circ} \mathrm{C}$ for $72 \mathrm{~h}$.

\section{Day +3}

Bystander cells in inserts were fixed in situ by using methanol and acetic acid $(4: 1 \mathrm{v} / \mathrm{v})$, for 20 minutes at $-20^{\circ} \mathrm{C}$. Samples were left to air-dry overnight.

\section{Day +4}

Inserts were mounted on slides for microscopy analysis by using Vectashield Mounting Medium with DAPI (4',6' diamino-2-phenylindole-2HCl) for nuclei staining..

Micronuclei (MN) were scored in binucleated (BN) cells using a 60x objective and classified according to standard criteria reported by Fenech et al 2007. Two different operators scored at least 2000 BN cells each in different areas of the same slide (one slide for each experimental condition) to evaluate the percentage of 
binucleated cells containing micronuclei (micronucleated cells or MNC) in the total number of BN cells (see Table 4.1).

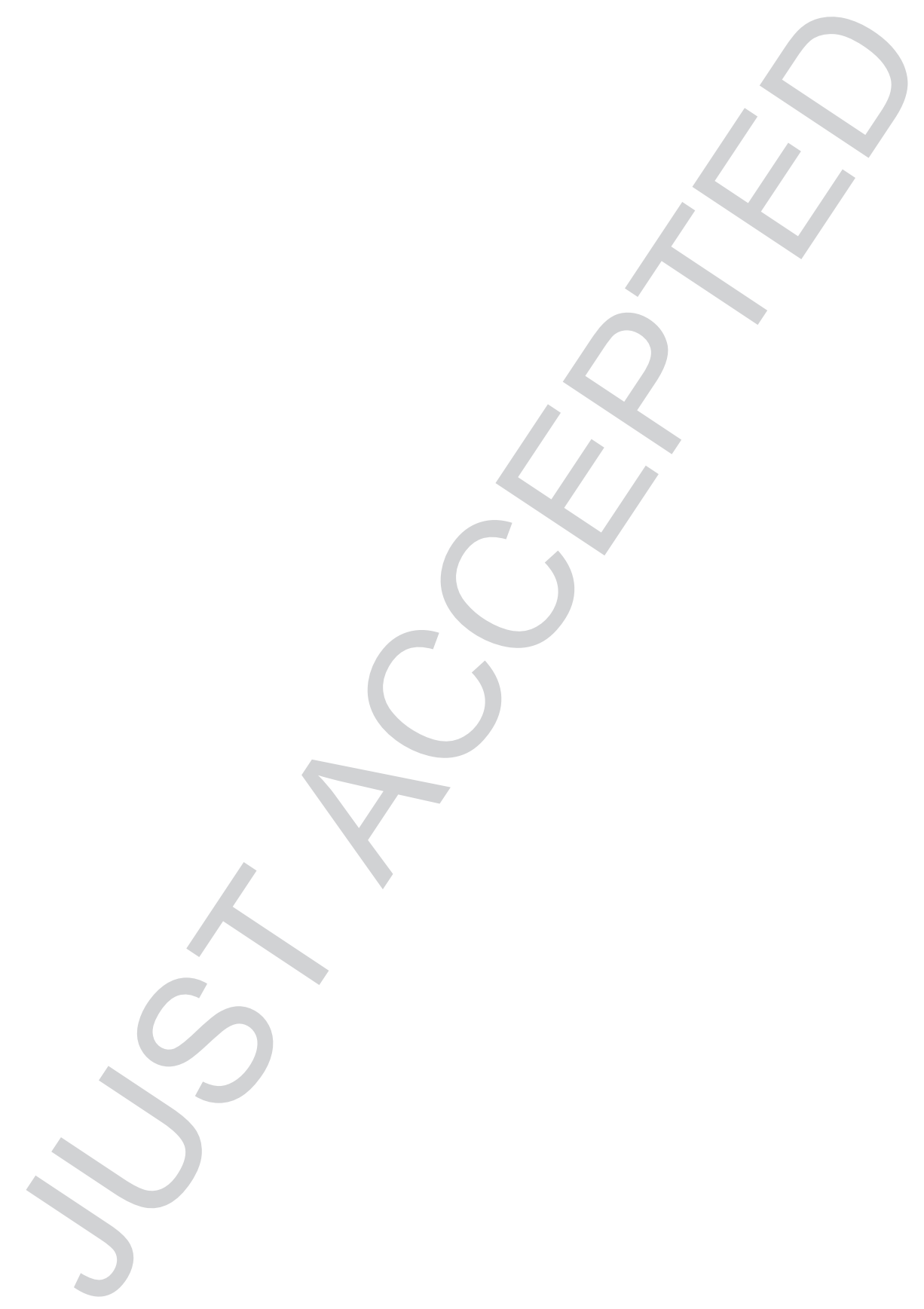




\section{Results and discussion}

In this study, the non-targeted effects of gamma rays were studied by assessing micronuclei induction in primary human fibroblasts (AG01522 cell line). Different batches of serum were compared with the aim of evaluating their effectiveness in inducing a bystander effect.

Besides serum 6 and serum 9, sent by Carmel Mothersill, two different sera currently used in our laboratory (serum $A$ and serum $B$ ) were tested. In total, 4 different media (Medium A, Medium B, Medium 6 and Medium 9) were prepared.

Cells from the same frozen vial were thawed, divided in four aliquots and cultured from the beginning of the experiment in the different media.

Because AG01522 primary human fibroblasts require $20 \%$ of serum in the culture medium, we couldn't prepare enough medium to repeat the experiment. To increase the statistical strength of the results obtained, at least 2000 binucleated cells in different areas of the same slide were scored by each of the two operators. Similar results were obtained (see Table 4.I), indicating a good homogeneity of the sample. The overall data were summed up and plotted with their statistical error in Fig.4.1.

For comparison, reference data on radiation induced micronuclei together with data from 8 bystander experiments, all obtained using serum A, were reported in Fig. 4.2

When using Medium 6, MN induction was not significantly different between bystander cells co-cultured with sham or $0.5 \mathrm{~Gy}$ irradiated cells, while a significant bystander response was observed with Medium 9, with the percentage of MNCs in bystander cells co-cultured with $0.5 \mathrm{~Gy}$ irradiated cells being about 1.3 fold that observed in bystander cells co-cultured with sham irradiated cells.

Also comparing Medium A and Medium B different bystander responses were observed. In particular, when Medium A was used, bystander cells co-cultured with sham or $0.5 \mathrm{~Gy}$ irradiated cells showed the same percentage of MNC, indicating no bystander effect. When these results are compared with the reference data set reported in Fig. 2, it appears that the major difference rely on the sham sample. However, it must be stressed that the value obtained in this experiment is compatible with the experimental variability of the reference data set. With Medium $B$, a significant bystander response was found with the percentage of MNC in bystander cells co-cultured with $0.5 \mathrm{~Gy}$ irradiated cells being about 1.6 fold that observed in bystander cells co-cultured with sham irradiated cells. This result is consistent with a previous measurement performed in a separate experiment with the same medium (data not shown).

In conclusion, in our experimental set up when we observed a radiation induced bystander response it was less than two-fold greater than that induced by the sham. Between the two sera received for testing, serum 9 seems to be more 
suitable than serum 6 to put in evidence a slight bystander effect in AG01522 primary human fibroblasts.

\section{Frédéric Joliot-Curie National Research Institute for Radiobiology and Radiohygiene (NRIRR )}

\section{Methods}

\section{Cell Culture and analysis of bystander effects}

F11-hTERT (human telomerase reverse transcriptase) immortalized human fibroblast cells were originally maintained in Dulbecco's modified Eagle's medium (DMEM) supplemented with $10 \%$ fetal calf serum (GIBCO-Biocult Ltd., Paisley, Scotland) and appropriate antibiotics. To investigate how the serotonin content of the applied serum modifies radiation-induced bystander effects, three sets of recipient and donor cells from the same frozen sample were seeded in $25 \mathrm{~cm}^{2}$ culture dishes at a density of $5 \times 10^{5}$ cells / dish. The medium of the first set contained $10 \%$ of our usual GIBCO fetal calf serum, the medium in the second and third sets composed of serum \#6 and \#9, provided by Prof. C. Mothersill. At this point the serotonin content of serum samples \#6 and \#9 was not known by us. We were only informed after the completion of the experiments that serum \#6 contained low serotonin levels, while serum \#9 high serotonin levels. Twenty four hours after seeding, cells were exposed at ambient temperature to $2 \mathrm{~Gy}{ }^{60} \mathrm{Co} \mathrm{y}$-rays (Gammatron-3; Siemens, Erlangen, Germany; dose rate, $0.0244 \mathrm{~Gy} / \mathrm{min}$ ) or sham irradiated. To investigate direct radiation effects, cells were incubated for 72 hours and then total cellular DNA was isolated and analyzed as described below. To study bystander effects irradiated donor fibroblasts were incubated for 2 hours, then the conditioned medium was harvested, filtered and transferred to unirradiated recipient cells which were cultured for an additional 72 hours then DNA was isolated. The experiments were performed under subdued light conditions to prevent serotonin degradation.

DNA isolation and analysis of mitochondrial DNA deletions by quantitative real-time polymerase chain reaction

Detection of radiation-induced deletions requires mitochondrial deoxyribose nucleic acid (mtDNA) replication; therefore cell-cultures were incubated at least for 72 hours after irradiation and then DNA was isolated both from the directly irradiated and bystander cells 72 hours after irradiation with MasterPure DNA Purification kit (EPICENTRE Biotechnologies, Madison, Wisconsin, USA). DNA purity and concentration were confirmed by spectrophotometer. The relative amount of wild type mtDNA copies and deleted mtDNA copies (CD) were measured by quantitative real time polymerase chain reaction (RT-PCR) as described recently (Schilling-Tóth el al, 2011). Briefly, mitochondrial DNA deletion-specific primer sets 
GGTTTCGATGATGAGGTCTTTG-3') flank the potential breakpoints such that amplification of the deletion-containing genomes yields an amplification product of 262 base-pairs. The short extension time $(30 \mathrm{sec})$ in the elongation phase of the $\mathrm{PCR}$ ensures the specific amplification of the deletion-containing genomes. Realtime quantitative PCR amplifications were carried out using SYBRGreen PCR kit in a $25 \mu \mathrm{l}$ reaction volume with $1 \mathrm{mg}$ DNA template, $2 \mathrm{U}$ Taq DNA polymerase (Maxima SYBR Green/ROX qPCR Master Mix Fermentas, Lithuania), in a RotorGene RG-3000A Real Time Thermal Cycler (Corbett Life Sciences, Mortlake, Australia). After denaturation at $95^{\circ} \mathrm{C}$ for $15 \mathrm{~min}$, the reaction mixture was cycled 40 times at $95^{\circ} \mathrm{C}$ for $30 \mathrm{sec}, 59^{\circ} \mathrm{C}$ for $30 \mathrm{sec}$ and $72^{\circ} \mathrm{C}$ for $30 \mathrm{sec}$, finally extended at $72^{\circ} \mathrm{C}$ for $10 \mathrm{~min}$. The specificity of the PCR products was checked by polyacrylamide gel electrophoresis. Reactions were made in duplicate and repeated at least twice from a minimum of three independent experiments. Expression patterns were normalized relative to the nuclear glyceraldehyde-3-phosphate dehydrogenase (GAPDH) gene, and to the total mitochondrial DNA content using the comparative Ct method in the Rotor-Gene version 6.0.33 software (Corbett Life Sciences).

For statistical analysis Pearson's t test were used. Differences were accepted as statistically significant if $p<0.05$.

\section{Results}

We estimated ${ }^{60} \mathrm{Co}$ gamma radiation induced direct and bystander effects by measuring common deletions (CD) in the mitochondrial genome in telomerase immortalized human fibroblast cells (F11-hTERT) using fetal calf serums with different serotonin levels. It is well documented that a $4977 \mathrm{bp}$ long region is frequently deleted from the mitochondrial genome after genotoxic stresses, including ionizing radiation. (Schilling-Tóth el al, 2011) Using appropriate deletion specific primers in PCR reactions only mitochondrial DNA carrying deletions is amplified therefore this protocol is suitable to measure low frequency events. As mentioned above, cells were cultured in three different serum samples, namely \#6 and \#9 with different serotonin content and also in our usual fetal calf serum (S). Bystander and direct responses were analyzed by the analysis of common deletions (CD) using quantitative real-time PCR. First, the effects of serum serotonin levels were investigated on direct radiation responses. When cells were grown in our usual serum 2 Gy radiation increased the amount of CD in the mitochondrial DNA by about $40 \%$ (Table 3.1). In the presence of low and high serotonins the amount of deleted mtDNA increased by about $73 \%$ and $26 \%$ (Table 5.1), respectively. The data might indicate that higher serum serotonin levels might induce higher levels of mtDNA damage, but the differences were not statistically significant. Regarding the bystander responses when cells were grown in our usual medium the amount of CD increased by about $38 \%$, which increase is basically 
indistinguishable from the effects of direct irradiation (Table 5.1). In the presence of low and high serotonin levels the frequency of common deletions increased similarly by $38 \%$ and $50 \%$, respectively.

In conclusion are data does not indicate a stronger radiation induced bystander response in the presence of higher serotonin levels in the culture medium.

\section{Institute of Medical Radiation Biology (UDE):}

Full paper in this issue.

\section{Oslo University Hospital (OUH):}

Full paper in this issue

\section{Oxford Brookes University (OBU)}

Full paper in this issue.

\section{Discussion and general conclusions}

The data from the seven laboratories do not give a clear "yes" or "no" answer to the question of whether high serotonin levels result in more pronounced bystander effects. One result was too variable to say whether there was an effect. In three cases the high serotonin serum was associated with different effects compared with the low serotonin serum but none was as dramatic as the original McMaster University finding. In two other cases the serum samples gave statistically identical results and in another case the level of significance was greater with the high serotonin serum. However given the wide range of assays used and cell types tested, it is perhaps expected that the role of serum would vary. It is interesting to note that the clearest effects were seen with the micronucleus endpoint and with the exception of the Radiation and Environmental Science Centre (RESC) data, with assays where cell death was being measured. This could suggest a very specific serotonin dependency related to activation of the calcium channel leading to initiation of apoptosis which was already demonstrated (Lyng et al 2002). Results by Lyng et al (2006) support this idea as they traced the downstream mitogen activated protein kinase (MAPK ) pathway in bystander signal

activated cells. The absence of a serum effect in the RESC data set is interesting because these cells have a very robust bystander response unlike the HPV-G cells which are also human skin keratinocytes. These have also been used by this group and continue to be used by the McMaster team. These two cell lines vary in the way 
immortalisation has been achieved. HaCaT cells (human skin keratinocytes) have a deletion on one strand of the p53 (protein 53) gene and a mutation on the other strand, meaning p53 expression is mutant (Lehman et al, 1993). HPV-G cells have wild-type p53 expression but it is only about $30 \%$ of normal (Pirisi et al, 1988). P53 is known to have a role in the expression of bystander responses (Mothersill et al, 2011) so this may explain some of the differences in the responses.

Findings from the MN assay performed at Oslo University Hospital support the hypothesis that serotonin levels in the medium play a role in the display of the bystander effect. Bystander cells receiving medium from irradiated cells in high serotonin conditions showed a modest but significant increase in MN formation, while the ones receiving medium with low serotonin levels did not show any bystander effect.

When using medium 6 or medium 9 , the background MN frequency observed in control cells was higher than the frequency seen in bystander controls grown in the reference medium. This could be attributed to the fact that the cells were not adapted to growing in the new media prior to the experiment. It could also explain why the background $\mathrm{MN}$ frequency did not change in the irradiated controls, since they were incubated with the new media for $20 \mathrm{~h}$ (the night prior to irradiation) and were replenished with reference medium $2 \mathrm{~h}$ after irradiation. The results from Oxford Brooks University using chromosomal analysis did not support the suggestions that serotonin levels in the medium play a role in the display of the bystander effect because all three sera induced significant chromosomal damage in both irradiated and bystander populations above their respective controls. Also there was no significant difference between bystander effect levels of the three serum samples .

An interesting outcome from this study is that it may be important to prescreen serum for the ability to demonstrate a bystander effect using a positive control in the particular assay in use in the laboratory. Clearly for some assays/cell lines, serum batch will not be an issue but for others it may be important to screen carefully before purchasing serum and to use the same batch for a series of experiments. There is a precedent for this in the literature on radiation transformation assays used in the 1980's where serum batch was critical for assays such as the $\mathrm{C} 3 \mathrm{H} 10 \mathrm{~T} 1 / 2$ focus formation assay (Terisima et al 1981)

In conclusion this inter-comparison exercise demonstrates that there are many types of bystander effect and probably not one common mechanism. Presence or absence of a an RIBE effect is known to be dependent on the endpoint examined, and the genetic background of the cell line or animal model. From these data it appears the environmental conditions also interplay with the other factors to influence expression. 


\section{Acknowledgements:}

This work was supported (or partially supported) by the NOTE IP 036465 (FI6R), Euratom specific programme for research and training on nuclear energy, 6th FP of the EC.

\section{Conflict of interest statement:}

The authors declare no conflict of interest

\section{References:}

Cherubini R, De Nadal V, Gerardi S, Guryev D. 2011. Lack of hyper-radiosensitivity and induced radioresistance and of bystander effect in V79 cells after proton irradiation of different energies. Radiation Protection Dosimetry 143: 315-319.

Fenech, M. 2007. Cytokinesis-block micronucleus cytome assay. Nature Protocols, 2:1084-1104.

Ferriere F, Khan NA, Meyniel JP, Deschaux P. 1997. 5-Hydroxytryptamine-induced calcium-channel gating in rainbow trout (Oncorhynchus mykiss) peripheral blood lymphocytes. Biochemical Journal 323: 251-258.

Fournier C, Barberet P, Pouthier T, Ritter S, Fischer B, Voss KO, Funayama T, Hamada N, Kobayashi Y, Taucher-Scholz G. 2009. No evidence for DNA and early cytogenetic damage in bystander cells after heavy-ion microirradiation at two facilities. Radiation Research 171: 530-540.

Groesser T, Cooper B, Rhydberg B. 2008. Lack of bystander effects from high-LET radiation for early cytogenetic end points. Radiation Research 170: 794-802.

http://www.chemicalbook.com/ChemicalProductProperty_EN_CB0245131.htm

Ivanova EV, Fraikin Gla. 1985. Effect of serotonin on the yield of UV- and $x$ ray-induced DNA damage. 50: 1374-1376.

Lehman TA, Modali R, Boukamp P, Stanek J, Bennett WP, Welsh JA, Metcalf RA, Stampfer MR, Fusenig N, Rogan EM, Harris CC. 1993. p53 mutations in human immortalized epithelial cell lines. Carcinogenesis 14: 833-839.

Lyng FM, Maguire P, McClean B, Seymour C, Mothersill C. 2006. The involvement of calcium and MAP kinase signalling pathways in the production of radiation-induced bystander effects. Radiation Research 165: 400-409.

Lyng FM, Seymour CB, Mothersill C. 2002. Early events in the apoptotic cascade initiated in cells treated with medium from the progeny of irradiated cells. Radiation Protection Dosimetry 99: 169-172.

Mothersill C, Bristow RG, Harding SM, Smith R, Mersov A, Seymour C. 2011. A role for p53 in the response of bystander cells to receipt of medium borne signals from irradiated cells. International Journal of Radiation Biology 87: 1120-1125

Mothersill C, Saroya R, Smith RW, Singh H, Seymour CB. 2010. Serum serotonin levels determine the magnitude and type of bystander effects in medium transfer experiments. Radiation Research 174: 119-123. 
Mothersill C, Seymour CB. 1998. Cell-cell contact during gamma irradiation is not required to induce a bystander effect in normal human keratinocytes: evidence for release during irradiation of a signal controlling survival into the medium. Radiation Research 149: 256-262.

Nagar S, Corcoran JJ, Morgan WF. 2006. Evaluating the delayed effects of cellular exposure to ionizing radiation. Methods in Molecular Biology 314: 43-50.

Pirisi L, Creek KE, Doniger J, DiPaolo JA. 1988. Continuous cell lines with altered growth and differentiation properties originate after transfection of human keratinocytes with human papillomavirus type 16 DNA. Carcinogenesis 9: 15731579.

Poon RC, Agnihotri N, Seymour C, Mothersill C. 2007. Bystander effects of ionizing radiation can be modulated by signalling amines. Environmental Research 105: 200211.

Ryan LA, Seymour CB, Joiner MC, Mothersill CE. 2008. Radiation-induced adaptive response is not seen in cell lines showing a bystander effect but is seen in lines showing HRS/IRR response. International Journal of Radiation Biology 85: 794-802.

Saroya R, Smith R, Seymour C, Mothersill C. 2009. Injection of resperpine into zebrafish prevents fish to fish communication of radiation-induced bystander signals: confirmation in vivo of a role for serotonin in the mechanism. Dose Response 8: 317330.

Schilling-Tóth B, Sándor N, Kis E, Kadhim M, Sáfrány G and Hegyesi H. 2011. Analysis of the common deletions in the mitochondrial DNA is a sensitive method to detect direct and non-targeted effects of low doses of ionizing radiation. Mutation Research - Fundamental Molecular Mechanisms, 716: 33-39.

Terasima T, Yasukawa M, Kimura M. 1981. Radiation-induced transformation of 10T 1/2 mouse cells in the plateau phase: post-irradiation changes and serum dependence. Gann. 72: 762-768.

Zyuzikov NA, Coates PJ, Parry JM, Lorimore SA, Wright EG. 2011. Lack of nontargeted effects in murine bone marrow after low-dose in vivo $X$ irradiation. Radiation Research 175: 322-327. 


\section{Table Legends}

Table 1.1

\begin{tabular}{|l|l|l|l|}
\hline Institution & Lead person & Assay & Result \\
\hline $\begin{array}{l}\text { STUK: Finnish Radiation } \\
\text { Protection Authority }\end{array}$ & Sisko Salomaa & $\begin{array}{l}\text { Viability and } \\
\text { caspase 3 activity }\end{array}$ & $\begin{array}{l}\text { Probably no serum } \\
\text { effect but data } \\
\text { inconclusive. }\end{array}$ \\
\hline $\begin{array}{l}\text { RESC: Radiation and } \\
\text { Environmental Science Centre }\end{array}$ & Fiona Lyng & $\begin{array}{l}\text { Clonogenic and } \\
\text { alamar blue } \\
\text { viability }\end{array}$ & No difference \\
\hline ISS:Istituto Superiore di Sanità & $\begin{array}{l}\text { Maria Antonella } \\
\text { Tabocchini }\end{array}$ & $\begin{array}{l}\text { Micronucleus } \\
\text { formation }\end{array}$ & $\begin{array}{l}\text { Bigger effect with } \\
\text { high serotonin serum }\end{array}$ \\
\hline $\begin{array}{l}\text { Hungarian Institute for } \\
\text { Radiobiology and Radiohygiene } \\
\text { (NRIRR) }\end{array}$ & Geza Safrany & $\begin{array}{l}\text { Mitochondrial } \\
\text { deletion }\end{array}$ & $\begin{array}{l}\text { Probably no serum } \\
\text { effect but data } \\
\text { inconclusive }\end{array}$ \\
\hline $\begin{array}{l}\text { UDE: Institute of Medical } \\
\text { Oncology }\end{array}$ & George Iliakis & G2 arrest & $\begin{array}{l}\text { Very clear low dose } \\
\text { effect with high } \\
\text { serotonin serum, } \\
\text { effect lost at higher } \\
\text { doses }\end{array}$ \\
\hline OUH : Oslo University Hospital & Jostein Dahle & $\begin{array}{l}\text { Micronucleus } \\
\text { formation }\end{array}$ & $\begin{array}{l}\text { More effect with high } \\
\text { serotonin serum }\end{array}$ \\
\hline $\begin{array}{l}\text { OBU: Oxford Brookes } \\
\text { University }\end{array}$ & Munira Kadhim & $\begin{array}{l}\text { Chromosomal } \\
\text { damage }\end{array}$ & $\begin{array}{l}\text { Slightly bigger effect } \\
\text { with high serotonin } \\
\text { serum but the serum } \\
\text { difference was not } \\
\text { statistically significant }\end{array}$ \\
\hline
\end{tabular}


Table 4.1 MN induction in bystander cells

\begin{tabular}{|c|c|c|c|c|c|c|c|c|c|}
\hline \multirow[b]{2}{*}{$\begin{array}{l}\text { sample } \\
\text { name }\end{array}$} & \multicolumn{3}{|c|}{ Operator 1} & \multicolumn{3}{|c|}{ Operator 2} & \multicolumn{3}{|c|}{$\begin{array}{c}\text { TOTAL } \\
\text { (Operator 1 + Operator 2) }\end{array}$} \\
\hline & BN & MNC & $\% \mathrm{MNC} \pm \mathrm{SD}$ & BN & MNC & $\% \mathrm{MNC} \pm \mathrm{SD}$ & BN & MNC & $\% \mathrm{MNC} \mid \pm \mathrm{SD}$ \\
\hline $\begin{array}{c}\text { Sham - } \\
\text { medium A }\end{array}$ & 2000 & 104 & $5.20 \pm 0.51$ & 2045 & 101 & $4.94 \pm 0.49$ & 4045 & 205 & $5.07 \pm 0.35$ \\
\hline $\begin{array}{c}\text { IR - } \\
\text { medium A }\end{array}$ & 2000 & 103 & $5.15 \pm 0.51$ & 2252 & 112 & $4.97 \pm 0.47$ & 4252 & 215 & $5.06 \pm 0.34$ \\
\hline $\begin{array}{l}\text { Sham - } \\
\text { medium B }\end{array}$ & 2053 & 68 & $3.31 \pm 0.40$ & 2140 & 63 & $2.94 \pm 0.37$ & 4193 & 131 & $3.12 \pm 0.27$ \\
\hline $\begin{array}{c}\text { IR - } \\
\text { medium B }\end{array}$ & 2000 & 104 & $5.20 \pm 0.51$ & 2091 & 101 & $4.83 \pm 0.48$ & 4091 & 205 & $5.01 \pm 0.35$ \\
\hline $\begin{array}{l}\text { Sham - } \\
\text { medium } 6\end{array}$ & 2000 & 86 & $4.30 \pm 0.46$ & 2012 & 86 & $4.27 \pm 0.46$ & 4012 & 172 & $4.29 \pm 0.33$ \\
\hline $\begin{array}{c}\text { IR - } \\
\text { medium } 6\end{array}$ & 2000 & 95 & $4.75 \pm 0.49$ & 2039 & 95 & $4.66 \pm 0.48$ & 4039 & 190 & $4.70 \pm 0.34$ \\
\hline $\begin{array}{c}\text { Sham } \\
\text { medium } 9\end{array}$ & 2000 & 112 & $5.60 \pm 0.53$ & 2013 & 112 & $5.56 \pm 0.53$ & 4013 & 224 & $5.58 \pm 0.37$ \\
\hline $\begin{array}{c}\text { IR - } \\
\text { medium } 9\end{array}$ & 2000 & 145 & $7.25 \pm 0.60$ & 2101 & 150 & $7.14 \pm 0.58$ & 4101 & 295 & $7.19 \pm 0.42$ \\
\hline
\end{tabular}

Sham - bystander cells co-cultured for $30 \mathrm{~min}$ with sham irradiated cells

IR-bystander cells co-cultured for $30 \mathrm{~min}$ with $0.5 \mathrm{~Gy}$ irradiated cells

SD - Standard deviation of the Poisson distribution for the number of BN cells 
Table 5.1. Relative amount of mitochondrial DNA deletions in directly irradiated and bystander cells. Fibroblasts growing in culture medium with different serotonin levels were either directly irradiated with 2 Gy or bystander responses were investigated in unirradiated cells by the addition of conditioned medium derived from cells irradiated by $2 \mathrm{~Gy}$. The amount of deletions in the mitochondrial genome was analyzed by quantitative real time PCR as described in Methods. Sera: S - reference fetal calf serum routinely used in our laboratory; \#6 fetal calf serum; \#9 - serum. CD - common deletion in mitochondrial DNA.

\begin{tabular}{|c|c|c|}
\hline Serum sample & Treatment & $\begin{array}{c}\text { Relative amount of } \\
\text { CD } \pm \text { SE }\end{array}$ \\
\hline S & directly irradiated & $1.41 \pm 0.23$ \\
\hline 6 & directly irradiated & $1.73 \pm 0.21$ \\
\hline 9 & directly irradiated & $1.26 \pm 0.07$ \\
\hline S & bystander response & $1.38 \pm 0.08$ \\
\hline 6 & bystander response & $1.42 \pm 0.17$ \\
\hline 9 & bystander response & $1.50 \pm 0.21$ \\
\hline
\end{tabular}




\section{Figure Legends}

Figure 2.1: Cell viability of bystander TK6 cells. Error bars represent standard errors of the mean. Results for serum 9 are significantly different from serum 6 in each case ( $n=3$ replicates but only $n=1$ biological experiment)

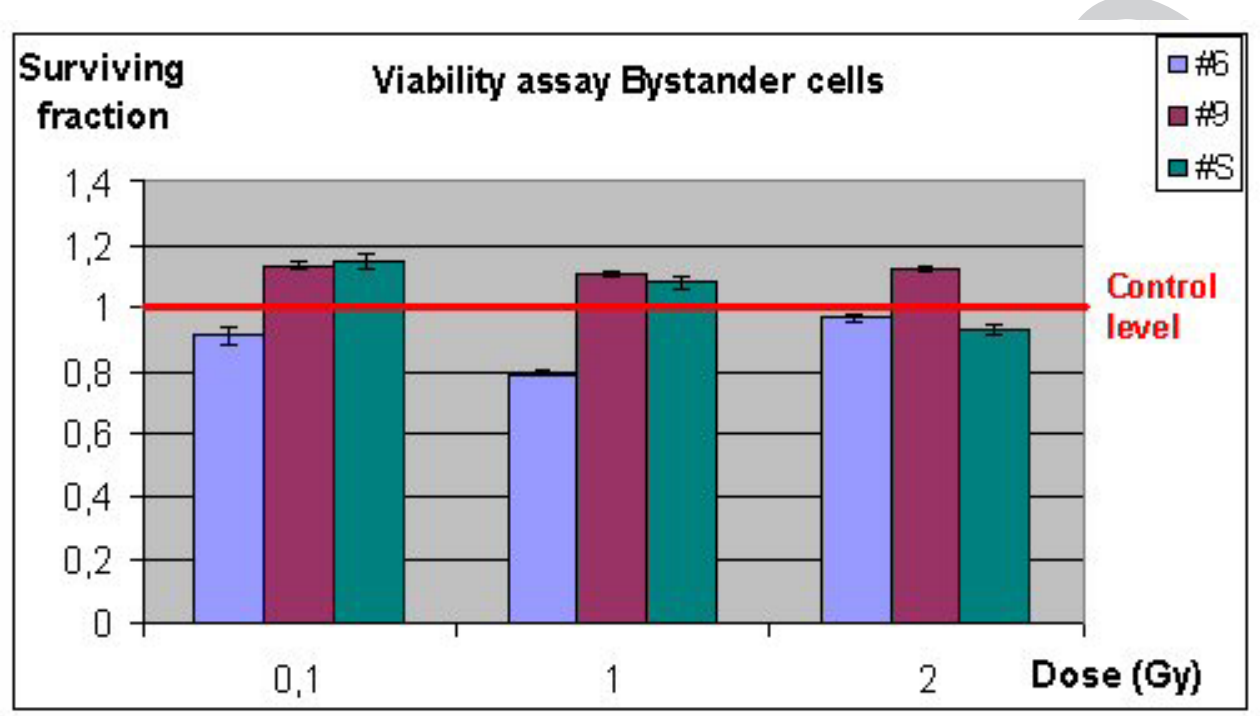


Figure 2.2: Measurement of caspase-3 activity in bystander TK 6 cells.

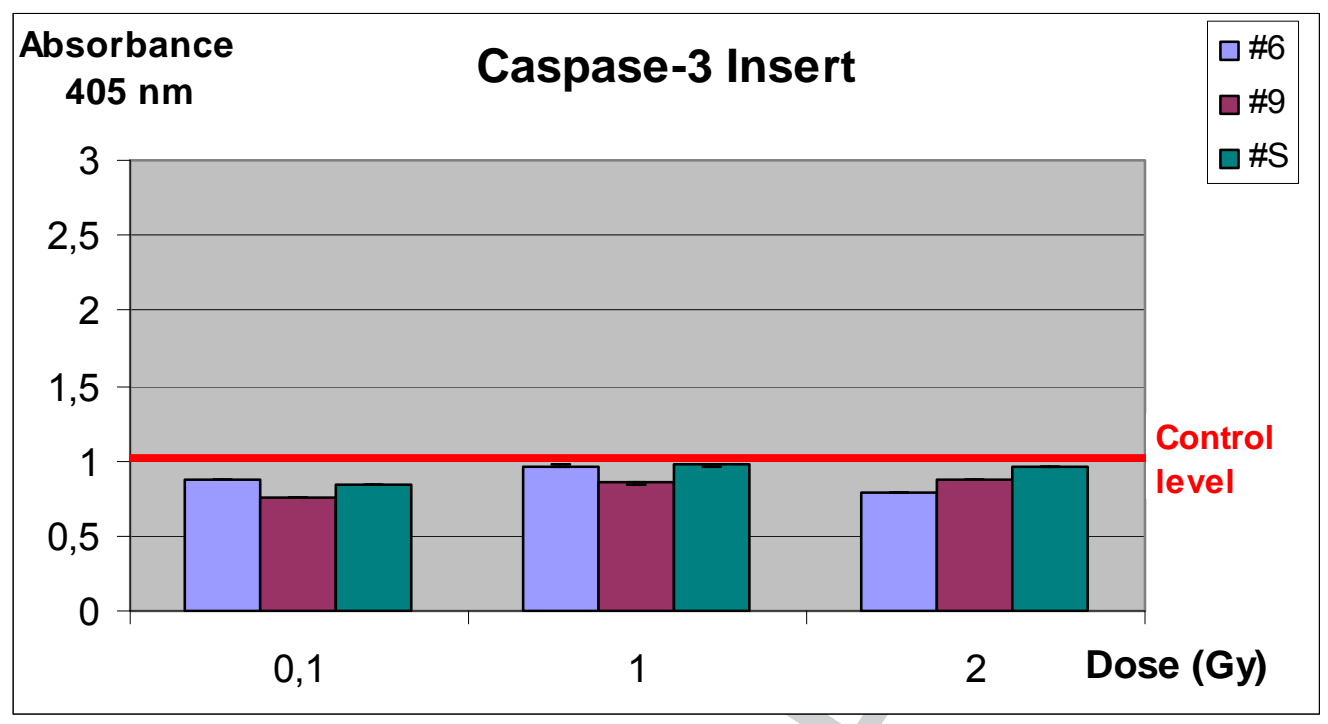


Fig. 4.1: Percentage of MNC in bystander cells co-cultured for 30 min with sham or $0.5 \mathrm{~Gy}$ irradiated cells. Data obtained by the scoring of a total of $4000 \mathrm{BN}$ cells are plotted with their Standard Deviation(SD). ${ }^{*} P<0.01\left(P(B)=1.35 \times 10^{-5} ; P(9)=3 \times 10^{-3}\right.$ ) relative to each sham.

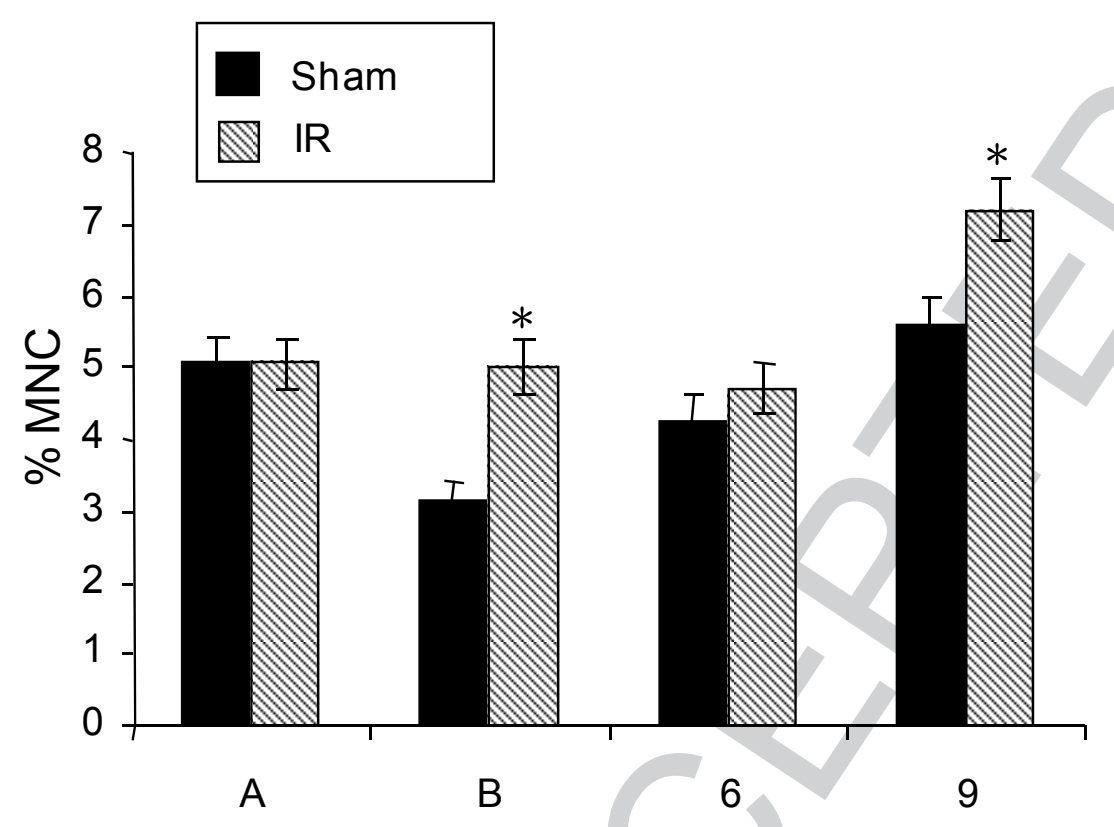


Fig. 4.2: Reference data: percentage of $M N C$ in: a) directly irradiated cells ( $0.5 \mathrm{~Gy})$ compared with non-irradiated control cells (mean of 3 exp); b) bystander cells cocultured for 30 min with $0.5 \mathrm{~Gy}$ irradiated cells compared with bystander cells cocultured for $30 \mathrm{~min}$ with sham-irradiated cells (mean of 8 exp). All experiments were performed by using serum $A$. Error bars represent the standard error of the mean (SEM). ${ }^{*} \mathrm{P}<0.01\left(\mathrm{P}(\mathrm{a})=9.0 \times 10^{-5}\right) ;{ }^{* *} \mathrm{P}<0.05\left(\mathrm{P}(\mathrm{b})=2.9 \times 10^{-2}\right.$ ) relative to $\mathrm{CN}(\mathrm{a})$ or Sham (b).

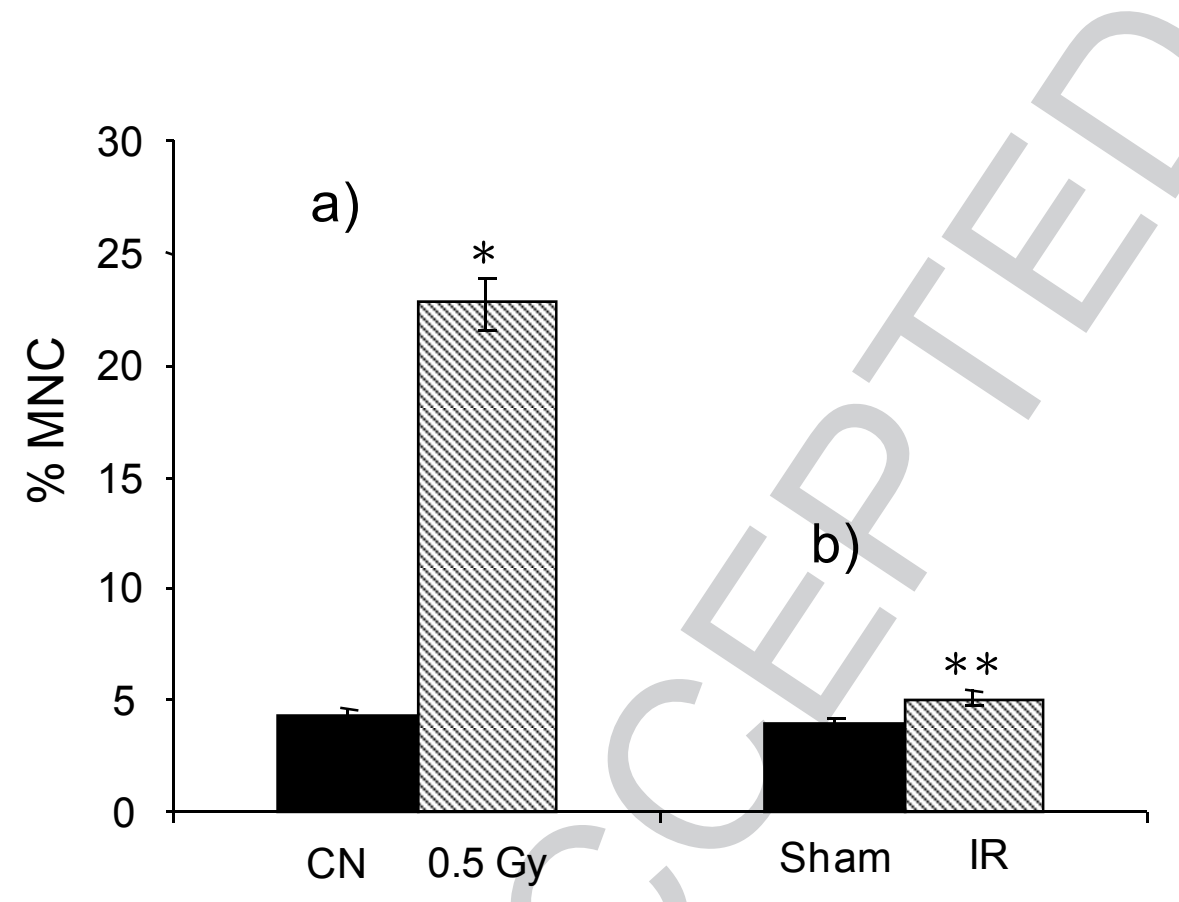

